Reprod. Nutr. Dévelop., 1980, 20 (3 A), 673-680.

\title{
In vivo change in the germinal vesicle of the sow oocyte during the follicular phase before the ovulatory LH surge
}

\author{
par Marie-Christine DAGUET
}

Université Pierre ef Marie Curie (Paris VI) and I. N. R. A. 78350 Jouy-en-josas, France.

\begin{abstract}
Summary. This study describes a morphological change in the germinal vesicle (GV) of the sow oocyte during the follicular phase preceding the ovulatory LH surge. Estrus synchronization oblained with methallibure treatment provided a reference point for dating the onset of the follicular phase of each sow in the experiment. The oocyte GV's of preovulafory follicles having a diameter of less than $2 \mathrm{~mm}$ (during the first 2 to 3 days of the follicular phase) showed uniformly dispersed chromatin with no condensation, while the GV's of oocytes from preovulatory follicles of more than $2 \mathrm{~mm}$ diameter (from days 2 and 3 of the follicular phase to day 5) presented condensed chromatin in the shape of a crown or horseshoe surrounding the nucleolus, and irregular chromatin clusters in the nucleoplasm; these clusters were usually found lying against the nuclear membrane.
\end{abstract}

\section{Introduction.}

The oocyte nucleus, called the germinal vesicle (GV), remains at the diplotene stage of the meiotic prophase (dictyate stage) from embryonic life to the time of the ovulatory LH surge, permitting resumption of meiosis at each cycle in oocytes within suitable follicles. The literature contains many references to GV breakdown and change resulting from the ovulatory LH surge, i. e. the first stages of the resumption of meiosis (rats : Odor, 1955 ; Mandl, 1963 ; mice : Edwards and Gates, 1959 ; Donahue, 1968 ; sows : Spalding ef al., 1955 ; Hunter and Polge, 1966 ; McGaughey and Polge, 1971 ; Motlik and Fulka, 1976), but little has been published on the development of the GV of oocytes from preovulatory follicles before the ovulatory LH surge.

This study reports developmental changes in the GV in sows during the first 5 days of the follicular phase. Sows were chosen as experimental animals because they have a relatively long (6-6.5 days) follicular phase which can be exactly dated at its onset after withdrawal of a methallibure treatment (Polge ef al., 1968). Moreover, it has been reported in the sow that dictyate oocytes can be ovulated if premature ovulation is induced by HCG injected on day 17 of the cycle, that is, 3 to 4 days before the natural LH surge (Hunter et al., 1976). Such a result suggests that changes must occur in the GV or in the oocyte, as well as in the follicle, before meiosis can resume. 


\section{Material and methods.}

Sixteen mature nulliparous or parous sows (Large White $\times$ Landrace hybrids) were studied ; 4 served as controls of a spontaneous estrous cycle and 12 were treated for estrus synchronization, as described by Polge ef al. (1968). Since methallibure treatment acts on the hypothalamo-pituitary axis, inhibiting gonadotropin release and thus follicular growth, its withdrawal provides a reference point for dating the onset of the follicular phase of each sow. Follicular growth resumes at a known date when the methallibure treatment is stopped. On day 1 (D1), an injection of $1000 \mathrm{IU}$ of PMSG was given to coordinate the onset of the follicular phase in all animals.

Individual sows were slaughtered on successive days after the treatment was withdrawn (D0 to D6), and the ovaries were removed a few minutes after slaughter. The following histological methods were used to study ovaries, pieces of ovary, previously isolated follicles or oocytes :

1) Bouin-Hollande fixation, paraffin wax embedding, material cut serially at $10 \mu$, hematoxylin-eosin staining ;

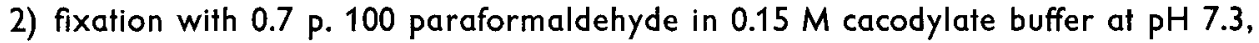
paraffin wax embedding, material cut serially at $6 \mu$, Feulgen-Fast Green staining or Toluidine Blue at $\mathrm{pH} 4.2$;

3) fixation with 0.7 p. 100 paraformaldehyde-2.5 p. 100 glutaraldehyde in $0.15 \mathrm{M}$ cacodylate buffer at $\mathrm{pH} 7.3$, Osmium postfixation, Epon embedding, material cut serially at $1 \mu$, staining with the method of Richardson ef al. (1960).

\section{Results.}

Morphological development of the GV was followed every day only in preovulatory follicle oocytes, that is, in the largest follicles of each ovary (the follicle diameter had been evaluated with a microscope) which were clear, well vascularized and without any sign of pyknosis (Daguet, 1978). A follicle was considered as atretic when it contained more than 4 pyknotic nuclei per $10 \mu$ section of granulosa.

Morphological changes in the GV were noted between D0 and D5, or during the period of the follicular phase preceding ovulatory LH surge.

\section{PLATE I}

Preantral follicle.

PHOTO 1. - The chromatin is despiralized ; note subcentral position of the GV in the oocyte. $10 \mu$ section ; hematoxylin-eosin staining. $\times 500$.

Preovulatory antral follicles : GV I stage ; chromatin is despiralized ; note peripheral position of the GV in the oocyte.

PHOTO 2. $-10 \mu$ section; hematoxylin-eosin staining. $\times 500$.

PHOTO 3. $-1 \mu$ section ; staining of Richardson et al. (1960). $\times 1250$. 
PI. I.
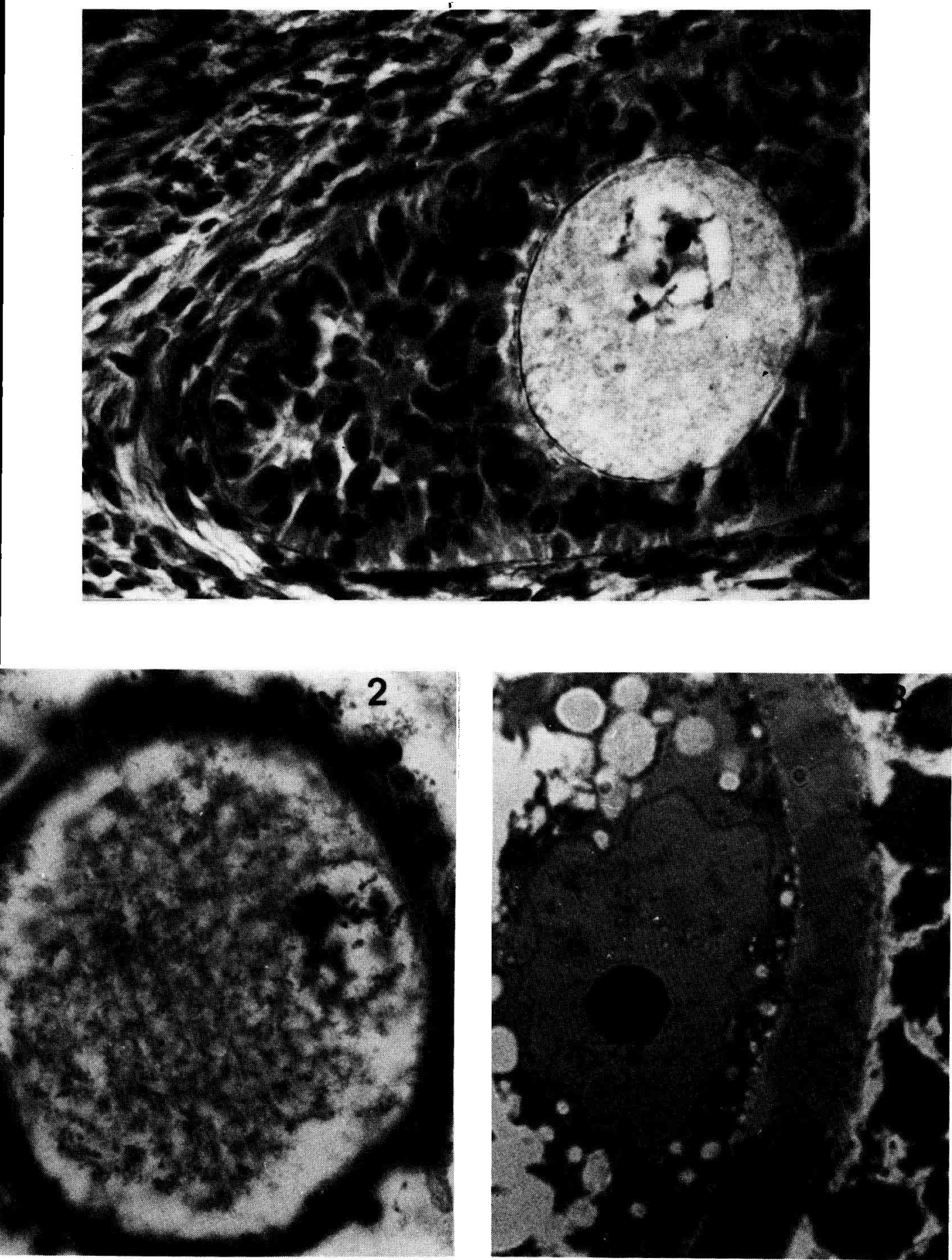
Description. - GV morphological development has been divided into two stages called GV I and GV II :

- GVI (photos 2, 3) : there was no significant condensation of the chromatin, which remained dispersed in the nucleoplasm. This stage was similar to that described in the oocytes of preantral follicles (photo 1). The only difference was the position of the GV : it was usually subcentral in oocytes of preantral follicles and peripheral in oocytes of preovulatory follicles.

- GV II (photos 4, 5, 6, 7) : the chromatin condensed in the form of a crown or horseshoe surrounding the nucleolus and in irregular clusters in the nucleoplasm; these clusters were usually lying against the nuclear membrane.

TABLE 1

Germinal vesicle (GV) stage in relation to follicular diameter and day of slaughter (characteristics of GV I and GV II are presented in the text)

\begin{tabular}{|c|c|c|c|c|c|}
\hline \multirow[b]{3}{*}{$\begin{array}{l}\text { Day of } \\
\text { slaughter }\end{array}$} & \multirow[b]{3}{*}{$\begin{array}{c}\text { Number of } \\
\text { oocytes } \\
\text { examined }\end{array}$} & \multicolumn{4}{|c|}{ Germinal vesicle stage } \\
\hline & & \multicolumn{2}{|c|}{ GVI } & \multicolumn{2}{|c|}{ GV II } \\
\hline & & P. 100 & $\begin{array}{c}\text { Follicle } \\
\text { diameters } \\
(\mathrm{mm})\end{array}$ & P. 100 & $\begin{array}{c}\text { Follicle } \\
\text { diameters } \\
(\mathrm{mm})\end{array}$ \\
\hline $\begin{array}{l}\mathrm{D} 0 \ldots \ldots \\
\mathrm{D} 1 \ldots \ldots \\
\mathrm{D} 2 \ldots \ldots \\
\mathrm{D} 2 \ldots \ldots \\
\mathrm{D} 5 \ldots \ldots\end{array}$ & $\begin{array}{r}7 \\
5 \\
20 \\
9 \\
5\end{array}$ & $\begin{array}{r}86 \\
100 \\
25\end{array}$ & $\begin{array}{l}1.1-1.6 \\
1.2-1.7 \\
1.2-1.9\end{array}$ & $\begin{array}{r}14 \\
75 \\
100 \\
100\end{array}$ & $\begin{array}{l}2 \\
2.1-4.3 \\
3.4-5 \\
4.6-5.1\end{array}$ \\
\hline
\end{tabular}

Chronology (table 1). - In all preovulatory follicles having a diameter of less than $2 \mathrm{~mm}$ (86 to 100 p. 100 at DO and D1, 25 p. 100 at D2), the oocyte GV was in the GV I stage. In preovulatory follicles having a diameter greater than $2 \mathrm{~mm}$ (75 p. 100 at D2, 100 p. 100 at D4 and D5), the oocyte was in GV II stage. (The development of follicle

\section{PLATE II}

Preovulatory antral follicles : GV II stage ; chromatin condensed in horseshoe shape around the nucleolus and in irregular clusters in the nucleoplasm; clusters usually lie against the nuclear membrane.

PHOTO $4: 10 \mu$ section, hematoxylin-eosin staining. $\times 500$.

PHOTO $5: 6 \mu$ section ; Feulgen-fast green staining. $\times 500$.

PHOTO $6: 6 \mu$ section; toluidine blue staining af $\mathrm{pH} 4.2 . \times 500$ (absence of background staining prevents visualization of oocyte cytoplasm).

PHOTO $7: 1 \mu$ section ; staining of Richardson ef al. (1960). $\times 1250$. Note the relation of the distinct clusters of chromatin to the nuclear membrane. Also note a dark mass and a light halo surrounding the nucleolus ; these correspond to two types of chromatin. 
diameter in relation to the time lag after withdrawal of the methallibure treatment is shown in figure 1.)

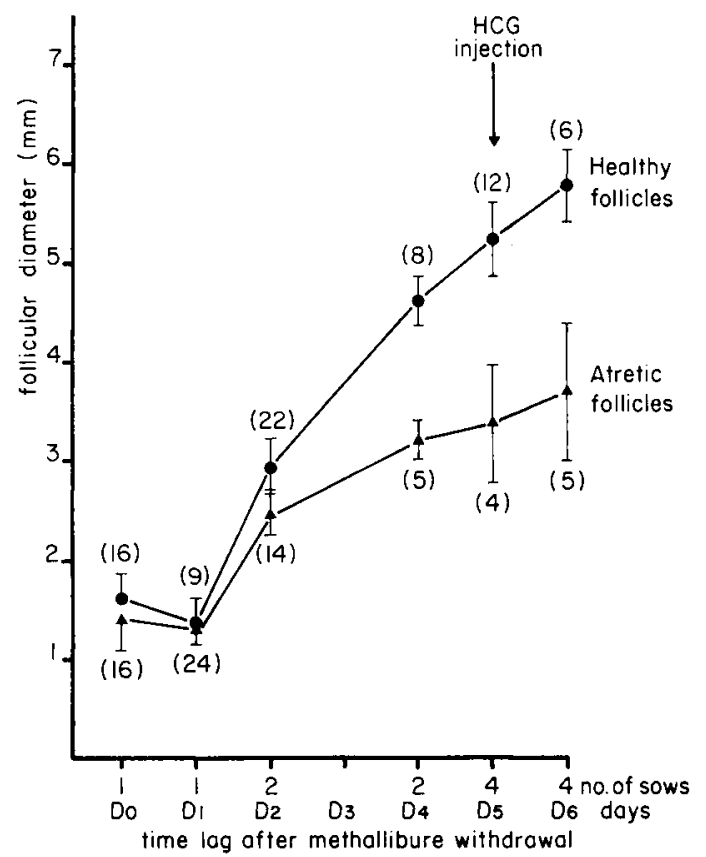

FIG. 1. - Increase of mean follicular diameters in relation to time lag after withdrawal of the methallibure treatment. Confidence interval : $\mathrm{P}=0.05 ;(\quad)$ : Number of follicles measured.

Thus, there were morphological changes in the chromatin condensation of the GV well before the ovulatory LH surge. The oocyte GV of control sows given no methallibure treatment and slaughtered at days 18 and 19 of a spontaneous estraus cycle, presented the same chromatin condensation surrounding the nucleolus as that observed in the methallibure-treated animals slaughtered at the same stage (D4-D5, when referring to the onset of estrus).

HCG injection given at D5 when follicular diameter is over $5 \mathrm{~mm}$, and consequently when the oocytes are in GV II, shows that such oocytes resume meiosis at a normal rate, according to Hunter and Polge (1966) and Motlik and Fulka (1976) : 24 hrs after HCG injection (at D6) 100 p. 100 of the oocytes were in the metaphase of the first meiotic division.

\section{Discussion.}

Many studies describe GV breakdown and change after HCG injection. However, this study reports the morphological development of the GV during the period of the follicular phase preceding the LH surge : (i) in the oocyte GV's of preovulatory follicles having a diameter smaller than $2 \mathrm{~mm}$, the chromatin was despiralized and no condensation was noted ; (ii) condensation occurred in the oocyte GV of preovulatory follicles having a diameter larger than $2 \mathrm{~mm}$; the chromatin was always condensed in the 
form of a horseshoe surrounding the nucleolus and in irregular clusters in the nucleoplasm. These clusters were usually found lying against the nuclear membrane. Thebault (personal communication) observed the same change in the chromatin condensation in the GV of rabbit oocytes during the preovulatory phase before $\mathrm{LH}$ surge. Many authors have observed the horseshoe-shaped chromatin around the GV nucleolus of preovulatory oocytes (mice : Edwards and Gates, 1959 ; Dohanue, 1968 ; sows : Hunter and Polge, 1966 ; Motlik and Fulka, 1976), but they did not describe the transformation of GV I into GV II observed in this study.

The following criticisms of this work may be made :

- that acid fixatives, such as the Bouin-Hollande used, sometimes induce chromatin condensation or retraction. If that is the case here, then that artefact should also be seen in the GV I stage. However, no chromatin condensation was found at that stage. Moreover, with aldehyde fixatives buffered at $\mathrm{pH} 7.3$, both stages were also found. The positive chromatin condensation with Feulgen reaction and Toluidine Blue (at $\mathrm{pH}$ 4.2), which specifically stained chromatin nucleic acids, confirms this interpretation;

- that the transformation of GV I into GV II during follicular phase might occur only in follicles which were atretic or potentially so. It was shown in Material andmethods that only healthy follicles were chosen each day from among the largest ones of each ovary; thus, only those which were supposed to ovulate (Daguef, 1978) were used.

The chromatin condensation prior to the LH surge would thus be a physiological phenomenon ; it might be the onset of a partial condensation leading to further condensation of the prometaphase, a process which has usually been described as the first sign of the resumption of meiosis after the ovulatory LH surge.

The nature of the « stimulus » triggering condensation of the GV chromatin 3 days before LH surge in unknown. However, one of the variable factors at that time was a rise in intrafollicular $17 \beta$-estradiol level between D2 and D3, according to Gerard ef al. (1979). It may be hypothesized that the increase of estradiol in the follicular fluid is the stimulus triggering condensation (those authors found no significant difference between treated and control sows as to the concentration of $17 \beta$-estradiol in the follicular fluid).

No definitive conclusion can be drawn concerning the exact nature of the perinucleolar chromatin crown since in this report no ultrastructural or histochemical studies were done on that material. When observed under the electronic microscope during GV I stage, the nucleolus had a particular structure which was different from that usually described in interphase of somatic cells (Szöllösi, personal communication), but similar to the structure found in the nucleolus of the oocyte nucleus of prepuberal mice (Chouinard, 1975).

These morphological changes in vivo in the GV well before the LH surge might explain some of the failures of in vitro oocyte maturation, if this early change is a necessary and important stage in the nuclear and cytoplasmic maturation of the oocyte. They might also explain why HCG, given 3 to 4 days before natural LH surge, can induce the ovulation of dictyate oocytes (Hunter et al., 1976).

Reçu en mai 1979.

Acceplé en novembre 1979. 
Acknowledgements. - I wish to thank Dr. D. Szöllösi and Dr. C. Thibault for their valuable advice, Mrs. Alice Daifuku for translating the manuscript and Mr. R. Scandolo for photographic assistance.

Résumé. Une transformation morphologique de la vésicule germinative de l'ovocyte de truie a éfé décrite pendant la période de la phase folliculaire qui précède la décharge ovulante de LH. Le traitement de synchronisation d'estrus par le méthallibure nous a permis de disposer d'un point fixe de référence permettant de dater le début de la phase folliculaire de chaque truie utilisée. Les vésicules germinatives d'ovocytes provenant de follicules préovulatoires de diamètre inférieur à $2 \mathrm{~mm}$ (c'est-à-dire pendant les 2 à 3 premiers jours de la phase folliculaire) présentent une chromatine uniformément répartie, sans aucune condensation, alors que les vésicules germinatives d'ovocytes provenant de follicules préovulatoires de diamètre supérieur à $2 \mathrm{~mm}$ (à partir du $2^{\mathrm{e}}$ et $3^{\mathrm{e}}$ jour de la phase folliculaire jusqu'au jour 5) possèdent une chromatine condensée en forme de couronne ou de fer à cheval autour du nucléole et en forme d'amas irréguliers situés dans le nucléoplasme, le plus souvent accolés à l'enveloppe nucléaire.

\section{References}

CHOUINARD L. A., 1975. A light and electron-microscopy study of the oocyte nucleus during development of the antral follicle in the prepubertal mouse. J. Cell Sci., 17, 589-615.

DAGUET M. C., 1978. Some aspects of final follicle growth in the sow. Ann. Biol. anim. Bioch. Biophys., 18, $1343-1349$.

DONAHUE R. P., 1968. Maturation of the mouse oocyte in vitro. 1) Sequence and timing of nuclear progression. J. exp. Zool., 169, 237-250.

EDWARDS R. G., GATES A. H., 1959. Timing of the stages of the maturation divisions, ovulation, fertilization and the first cleavage of eggs of adult mice treated with gonadotrophins. $J$. Endocrin., 18, 292-304.

GÉRARD M., MÉNÉZO Y., ROMBAUTS P., SZÖLLÖSI D., THIBAULT C., 1979. In vitro studies of oocyte maturation and follicular metabolism in the pig. Ann. Biol. anim. Bioch. Biophys., 19, $1521-1536$.

HUNTER R. H. F., COOK B., BAKER T. G., 1976. Dissociation of response to injected gonadoiropin between the Graafian follicle and oocytes in pigs. Nature, 260, 156-158.

HUNTER R. H. F., POLGE C., 1966. Maturation of follicular oocytes in the pig after injection of human chorionic gonadotrophin. J. Reprod. Fert., 12, 525-531.

MANDL A. M., 1963. Pre-ovulatory changes in the oocyte of the adult rat. Proc. roy. Soc. B, 158, 105-118.

MCGAUGHEY R. W., POLGE C., 1971. Cytogenetic analysis of pig oocytes matured in vitro. J. exp. Zool., 176, 383-396.

MOTLIK J., FULKA J., 1976. Breakdown of the germinal vesicle in pig oocytes in vivo and in vitro. J. exp. Zool., 198, 155-162.

ODOR D. L., 1955. The temporal relationship of the first maturation of rat ova to the onset of heat. Amer. J. Anat., 97, 461-491.

POLGE C., DAY B. N., GROVES T. W., 1968. Synchronization of ovulation and artificial insemination in pigs. Vet. Rec., 83, 136-142.

RICHARDSON K. G., JARRETT L., FINKE E. H., 1960. Embedding in epoxy resins for ultrathin sectioning in electron microscopy. Stain Techn., 35, 313-323.

SPALDING J. F., BERRY R. O., MOFFIT J. G., 1955. The maturation process of the ovum of swine during normal and induced ovulation. J. Anim. Sci., 14, 609-620. 